Benha Veterinary Medical Journal
Official Journal Issued by
Faculty of
Veterinary Medicine $\quad$ Journal homepage: https://bvmj.journals.ekb.eg/

Original Paper

\title{
Chemical residues in burger and sausage meat products
}

Ellia Y. M. Abd El Shahid ${ }^{1}$, Mohamed A. El. Shater', Mohamed A. Hasan', Hemmat M. Ibrahim²

1Department of Food Hygiene and Control, Agri. Res. Center, Animal Health Res. Institute, Dokki- Giza.

${ }^{2}$ Department of Food Hygiene and Control. Faculty of Veterinary Medicine, Benha University

\begin{tabular}{|c|c|}
\hline ARTICLE INFO & ABSTRACT \\
\hline $\begin{array}{l}\text { Keywords } \\
\text { Chemical residues } \\
\text { Heavy metals } \\
\text { Meat products } \\
\text { pesticides } \\
\text { Zeranol } \\
\text { Trenbolone }\end{array}$ & $\begin{array}{l}\text { This study was designed to detect some chemical contaminants in burger and sausage. A total } \\
\text { of } 150 \text { samples of burger and sausage meat products ( } 75 \text { of each) were collected from different } \\
\text { local markets in Giza governorate, Egypt. Samples were subjected to determination of residue } \\
\text { levels of antibiotics, zeranol and trenbolone hormones, heavy metals and pesticides. The } \\
\text { incidence of antibiotics, organophosphorus pesticides (OPPs) and arsenic (As) residues levels } \\
\text { were not detected in all examined samples of meat products, while zeranol residue incidence } \\
\text { in burger was zero and } 100 \% \text { sausage samples with mean value of ( } 0.3721 \text { ppb). The } \\
\text { trenbolone residues was recorded in all examined samples of both burger and sausage with } \\
\text { mean values of }(0.1368 \text { ppb) and ( } 0.14367 \mathrm{ppb),} \mathrm{respectively.} \mathrm{Lead} \mathrm{was} \mathrm{detected} \mathrm{in} \mathrm{all} \mathrm{samples} \\
\text { of burger ( } 100 \%) \text { with mean value of }(0.04844 \mathrm{ppm}) \text { and ( } 67 \%) \text { of sausage with mean value } \\
\text { of ( } 0.2575 \text { ppm). Cadmium was recorded in }(67 \%) \text { of burger while it was not recorded in any } \\
\text { of sausage samples. The zinc residues was present in all examined samples of burger and } \\
\text { sausage with mean value of ( } 0.44784 \text { ppm) and ( } 0.6132 \text { ppm), respectively. The residues of } \\
\text { PP.DDT were recorded in all examined samples of burger and sausage. The mean value of } \\
\text { PP.DDT in sausage (2.476 ppm) was higher than in burger (1.92004 ppm). The residues of } \\
\text { methoxychlor were recorded only in burger samples with mean value ( } 49.66062 \text { ppm) while } \\
\text { methoxychlor not recorded in sausage samples. Endrin only recorded in burger samples with } \\
\text { mean value ( } 0.716 \text { ppm) but sausage samples were free. The PP. DDD was recoded in all burger } \\
\text { and sausage samples with mean values ( } 0.464 \text { ppm) and ( } 0.614 \text { ppm). In this study four types } \\
\text { of (OCP) residues were recorded in burger sample, while only two types of (OCP) residues } \\
\text { recorded in sausage samples. Accordingly, it seems that such residues as, antibiotics, } \\
\text { hormones, heavy metals and pesticides in some meat products constitute a public health hazard, } \\
\text { so we need to routinely monitor these chemical residues as food quality control measure }\end{array}$ \\
\hline
\end{tabular}

\section{INTRODUCTION}

Meat and meat products are important for nutrition and the human diet, but also, one of the major routs of human intake contaminants such as (antibiotics, hormones, heavy metals, and pesticides), contaminated substances may enter the food chain at many different stages. These contaminants in forages and other foods can transmitted to animal products, veterinary drugs can leave residues in animal products (Heena Jalal et al., 2015).

The administration of health risk related substances such as growth promoting agents and hormones is recurring problem in animal production where the compounds are often used to increase the productivity and to reduce breeding cost (Toffolatti et al., 2006). There are many routs for human exposure to lead and cadmium. Individuals be aware of the health effects resulting from consumption of heavy metal contaminated food products. While the food chain constitutes a main source of accumulation of such heavy metals.

Meat products represent an essential part of the human diet and are consumed mostly on daily basis. This makes them a continuous source of exposure to lead and cadmium. Thus, leading to various diseases liked to the toxicity of such metals. Accordingly, it is important to determine their levels in meat and meat products to assess the health risks derived from their consumption. The level of heavy metals in meat and meat products depend on several factors such as the environmental conditions, grazing land, and the genetic characteristics of the animal's organism (Demirezen et al., 2006).

The use of pesticides and other highly toxic chemicals like DDT on crops can lead to cancer, infertility, and diseases of liver in animals. Toxins like DDT can diffuse into fat and are stored in animal fat. Among the pesticides chlorinated hydrocarbons (aldrin, endrin, dieldrin, heptachlor, toxaphene, etc.) have been the worst culprit (Rama et al., 2016).

This study was planned to evaluate the residue levels of antibiotics, zeranol hormone, trenbolore hormone, heavy metals (Lead, cadmium, zinc, and arsenic) and pesticides (organochlorine and organophosphorus) in burger and sausage meat products.

\section{MATERIAL AND METHODS}

2.1 Collection of samples:

A total of 150 samples of burger and sausage meat products (75 of each) were collected from local markets in Giza

\footnotetext{
* Corresponding author: yossefellia@gmail.com
} 
governorate. The samples were transferred into ice box to animal health research institute (Giza branch laboratory). All samples were kept at $-18^{\circ} \mathrm{C}$ for further investigation as fast as possible without delay.

\subsection{Methods}

2.2.1. Determination of Antibiotics residues in meat products

The method was carried out according the Heitzman (1990) using microbiological assay

2.2.2. Determination of anabolic steroid residues

2.2.2.1. Detection of zeranol residues by (ELISA) method according to Biopharm AG-Darmstadt, Germany: RIDASCREEN® Zeranol, Enzyme Immunoassay for quantitative analysis of zeranol

2.2.2.2. Detection of trenbolone residues: by (ELISA) method) according to: R- Biopharm AG-Darmstadt, Germany: RIDASCREEN@ Trenbolone, Enzyme Immunoassay for the quantitive analysis of trenbolone (ART, No.: R2601).

2.2.3.Determination of heavy metals (Lead, Cadmium,

Zink and Arsenic)

It was Carried out according to Staniskiane et al. (2006) and Chawdnury et al. (2011) using Atomic Absorption flam emission Spectrophotometer model AAS - 240FS Varian Australia.

The samples were digested by wet digestion method.

AOAC Official method 970.52 (1996)

2.2.4. Detection of Pesticides

The detection of organophosphorus and organochlorine pesticides were carried out according to JAOAC (1974) using Gas Chromatography (GC).

\subsection{Statistical Analysis (S.A.S, 2001):}

Numerical data collected were statistically analyzed for analysis of variance and least significant difference.

Chi-square, $t$. test and correlation were calculated when required.

\section{RESULTS}

This study revealed that the incidence percent of antibiotics, organophosphate pesticides (OPPs), and arsenic residues were zero in all examined burger and sausage samples. The residues of hormones were illustrated in table 1: which shows that the zeranol residues were zero in all examined burger samples (75) $100 \%$ whereas it was recorded in all examined sausage samples (75) $100 \%$ with mean value $(0.3721 \mathrm{ppb})$. Whereas 75 of burger samples $(100 \%)$ harbor residues of trenbolone. The mean value of trenbolone residues in burger samples was $(0.1368 \pm 0.069 \mathrm{ppb})$ with range $(0.02-0.022 \mathrm{ppb})$. The hormone residues were recorded in all examined sausage samples (75) $100 \%$ for either zeranol or trenbolone with mean value $(0.3721 \pm$ $0.0263 \mathrm{ppb})$ and $(0.1437 \pm 0.0152 \mathrm{ppb})$ respectively. Results in table 2: showed that the mean values of some heavy metals (Lead, cadmium) in burger samples were $(0.04844$ ppm), (0.00298 ppm), respectively. The percent of positive samples for lead $(100 \%)$ and $(67 \%)$ for cadmium. The concentration of lead residues (ppm) mean value in examined sausage samples was $(0.2575) \mathrm{ppm}$. The number of positive samples of sausage harbor lead residues was 50 samples $(67 \%)$ with range $(0.05$ to $0.47 \mathrm{ppm})$.On the other hand, the cadmium residues were not detected in any of sausage samples. table 3. illustrated that none of examined burger samples have arsenic residues. Concerning the zinc residues in burger samples, $100 \%$ of the samples contain zinc residues with mean value $(0.44784 \mathrm{ppm})$. On the other hand, the arsenic residues were not detected in any of sausage samples, whereas the zinc residues were recorded in 75 samples $(100 \%)$ of sausage. The average zinc residue level was $(0.6132 \mathrm{ppm})$. The organochlorine pesticide (OCPs) residues were examined in burger and sausage samples in this study. Results in table 4:revealed that 12 types of OCP which are: Alfa- BHC, gamma BHC, delta $\mathrm{BHC}$, heptachlor, aldrin, heptachlor epoxide endosulfan, dieldrin, PP-DDE, endosulfan 11, endrin aldehyde and endosulfan sulfate were not detected in burger examined samples. The last four detected types of OCP were: endrin, PP-DDD, PP-DDT and Methoxychlor. The lowest value was recorded for PP-DDD (0.464 ppm) while the highest value was recorded for Methoxychlor (49.66062 ppm). The PPDDT was relatively higher (1.9004 ppm) than endrin $(0.716$ $\mathrm{ppm})$. The examined sausage samples harbor only two OCP residues: PP- DDD and PP-DDT were 0.614 (ppm) and 2.476 (ppm) respectively. On the other hand, the other recorded (OCP) in table 4 were not detected in examined sausage samples.

\section{DISCUSSION}

The absence of zeranol hormone in examined burger samples may be due to the effect of freezing on the reduction of zeranol, this agree with the results recorded by (Maykola, 2020). Zeranol and trenbolone MRLs 2 ppb in cattle muscle and $10 \mathrm{ppb}$ in cattle liver (Codex Alimentarious 1997 and EC 1999). This show that the examined samples of burger were not exceed the mentioned MRLs by Codex 1997 and EC 1999.

Table 1 Hormone residues in examined burger and sausage samples (No of each $=75$ )

\begin{tabular}{|c|c|c|c|c|c|c|c|c|c|c|c|c|}
\hline \multirow[t]{2}{*}{ Type of sample } & \multicolumn{6}{|c|}{ Zeranol (ppb) } & \multicolumn{6}{|c|}{ Trenbolone (ppb) } \\
\hline & No of $+\mathrm{ve}$ & $\%$ of $+v e$ & Min & Max & Mean & $\mathrm{SE} \pm$ & No of $+\mathrm{ve}$ & $\%$ of $+\mathrm{ve}$ & Min & Max & Mean & $\mathrm{SE} \pm$ \\
\hline Burger & 0 & $0 \%$ & 0 & 0 & 0 & 0 & 75 & $100 \%$ & 0.02 & 0.22 & 0.1368 & 0.0069 \\
\hline Sausage & 75 & $100 \%$ & 0.1 & 0.9 & 0.3721 & 0.0263 & 75 & $100 \%$ & 0.03 & 0.35 & 0.1437 & 0.0152 \\
\hline
\end{tabular}

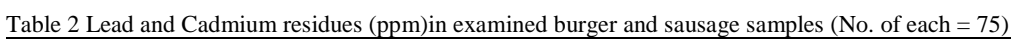

\begin{tabular}{|c|c|c|c|c|c|c|c|c|c|c|c|c|}
\hline \multirow{2}{*}{ Type of sample } & \multicolumn{6}{|c|}{ Lead (ppm) } & \multicolumn{6}{|c|}{ Cadmium (ppm) } \\
\hline & No of $+v e$ & $\%$ of $+\mathrm{ve}$ & Min & $\operatorname{Max}$ & Mean & $\mathrm{SE} \pm$ & No of $+v e$ & $\%$ of $+\mathrm{ve}$ & Min & $\operatorname{Max}$ & Mean & $\mathrm{SE} \pm$ \\
\hline Burger & 75 & $100 \%$ & 0.04 & 0.06 & 0.04844 & 0.0008 & 50 & $67 \%$ & 0.001 & 0.006 & 0.00298 & 0.00023 \\
\hline Sausage & 50 & $67 \%$ & 0.05 & 0.47 & 0.2575 & 0.0293 & 0 & $0 \%$ & 0 & 0 & 0 & 0 \\
\hline
\end{tabular}

Table 3 Arsenic and Zinc residues(ppm) in examined burger and sausage samples (No. of each $=75$ )

\begin{tabular}{|c|c|c|c|c|c|c|c|c|c|c|c|c|}
\hline \multirow{2}{*}{ Type of sample } & \multicolumn{6}{|c|}{ Arsenic (ppm) } & \multicolumn{6}{|c|}{ Zinc (ppm) } \\
\hline & No of $+\mathrm{ve}$ & $\%$ of $+\mathrm{ve}$ & Min & Max & Mean & $\mathrm{SE} \pm$ & No of $+\mathrm{ve}$ & $\%$ of $+\mathrm{ve}$ & Min & $\operatorname{Max}$ & Mean & $\mathrm{SE} \pm$ \\
\hline Burger & 0 & $0 \%$ & 0 & 0 & 0 & 0 & 75 & $100 \%$ & 0.37 & 0.529 & 0.44784 & 0.00725 \\
\hline Sausage & 0 & $0 \%$ & 0 & 0 & 0 & 0 & 75 & $100 \%$ & 0.345 & 0.789 & 0.6132 & 0.0223 \\
\hline
\end{tabular}


Table 4. Organochlorine pesticide residues by (Gas Chromatography) in examined burger and sausage samples (No. of each $=75$ )

\begin{tabular}{|c|c|c|c|c|}
\hline \multirow{2}{*}{ Name of (OCP) } & \multicolumn{2}{|c|}{ Burger } & \multicolumn{2}{|c|}{ Sausage } \\
\hline & Detected residues (ug/ul) & Calculated residues (ppm) & Detected residues (ug/ul) & Calculated residues (ppm) \\
\hline 1- Alfa - BHC & - & - & - & - \\
\hline 2- Gama - BHC & - & - & - & - \\
\hline 3- Delta - BHC & - & - & - & - \\
\hline 4- Heptachlor & - & - & - & - \\
\hline 5- Aldrin & - & - & - & - \\
\hline 6- Heptachlor epoxide & - & - & - & - \\
\hline 7- Endosulfan & - & - & - & - \\
\hline 8- Dieldrin & - & - & - & - \\
\hline 9- PP DDE & - & - & - & - \\
\hline 10- Endrin & $1.94579 \mathrm{e}^{-1}$ & 0.716 & - & - \\
\hline 11- Endosulfan 11 & - & - & - & - \\
\hline 12- PP. DDD & $1.26100 \mathrm{e}^{-1}$ & 0.454 & $4.53722^{-2}$ & 0.614 \\
\hline 13- Endrin aldehyde & - & - & - & - \\
\hline 14- Endosulfan sulfate & - & - & - & - \\
\hline 15- PP-DDT & 1.92004 & 1.92004 & $6.73172^{-2}$ & 2.476 \\
\hline 16- Methoxychlor & 49.66062 & 49.66062 & - & - \\
\hline
\end{tabular}

The mean residues of both zeranol and trenbolone in the examined sausage samples within the MRLs recommended by Codex (1997) and EC (1999) for both zeranol and trenbolone. The MRLs of (EU 2006) for lead and cadmium 0.1 and $0.05 \mathrm{ppm}$ in lean meat respectively. According to the MRLs recommended by (EU 2006), the examined burger samples in this study were accepted. In the present study lower results of both lead and zinc while absent of both cadmium and arsenic. According to the MRLs recommended by (EU, 2006) for lead and cadmium the mean value of lead in examined sausage samples was rejected. Lead poisonous has neurotoxic effect, cellular inactivation binds to gastrointestinal enzymes and renal systems (Emin et al., 2010). Cadmium accumulate in kidneys and it has an extremely long biological half-life in humans in the order of 20-30 years WHO (2009). The main exposure to heavy metals usually comes from food. After continuously evaluating studies on food additives and their toxicity, the WHO has come to the conclusion that even low levels of some metals, such as lead and cadmium, can give rise to diseases in humans (WHO, 2000; 2001).Organochlorines are DDT, DDD, dicofol, endrin, dieldrin, chlorobenilate, lindane, BHC, Methoxychlor, aldrin, chlordane, heptachlor, endosulfan, isordil, toxaphene, chlorpropylat (Ravidran, 2016). On contrary these OCPs were detected in all examined meat and meat products (Herrera et al., 1994). The endrin has moderate persistence half-life ( 1 day to 12 years) and highly hazardous. The PP-DDD is high persistence half-life (5-10 years), acute hazard is unlikely. On the same concern PPDDT has high persistence half-life (2-15 years), moderately hazardous, whereas the Methoxychlor has high persistence half-life $<120$ days and acute hazard is unlikely. There different processing stages including mincing, stuffing and storage either chilling or freezing of fresh sausage may be the cause of absence of most organophosphorus pesticides and the low detected range of both PP-DDD and PP-DDT, 0.614 and $2.476(\mathrm{ppm})$ respectively, this result may agree with that reported by (Sharma et al., 2005). According to EC 2004and FAO/WHO 2017 MRLs for PP-DDT is 5 ppm in meat, it is mean that the examined meat products (burger and sausage) were not exceed the fore mentioned MRLs. On the other hand, the OCP Methoxychlor only detected in burger samples with value 49.66 (ppm). The MRLs of Methoxychlor recommended by EC (2004) and FAO/WHO(2016) is $0.01 \mathrm{ppm}$. Accordingly, the Methoxychlor exceeds this limit in burger meat product. It is obvious from present data that four types of OCP residues were recorded in burger samples whereas two types of OCP residues only were recorded in sausage samples. Many of the organochlorine molecules are carcinogenic and neurotoxic (Kaiser, 2000).

\section{CONCULOSIONS}

It could be concluded from this study that analysis of burger and sausage meat products indicated such meat products were contaminated with hormone residues, heavy metal residues and organochlorine pesticide residues (OCPs), while these products were free from antibiotic residues and organophosphorus pesticide residues (OPPs)when they are investigated. Although most of these residues (Hormone residues, heavy metal residues and organochlorine pesticide residues (OCPs) occurred at very low concentrations in the examined samples, they accumulate to higher levels in human beings who consume these products. So, it is recommended that: 1-Strict analysis of meat products at different localities and the presence of antibiotics, hormones, heavy metals, and pesticides in such products above the recommended permissible limits (MRL) should be rejected. 2-Also, better selections of the raw material including an analysis of toxic chemicals prior to processing could sourly improve situation. 3- meat products must be labeled by official organization to indicate the levels of antibiotics, hormones, heave metals and pesticides.

\section{REFERENCES}

1. AOAC (Association Official Analytical Chemists). 1996 Official methods of the Association Official Analytical Chemist Washington, D.C

2. Chawdnury, M.Z., Siddique, Z.A., Hossain, S.M., Kazi, A.I., Ahsan, M.A., Ahmed, S., Zaman, M.M. 2011. Determination of essential and toxic metals in meats, meat products and eggs by spectrophotometric method. Department of chemistry, University of Chittagong. Chittagong Bangladesh; BCSIR laboratories, Dhaka, Bangladesh; BCSIR Laboratories, Chittagong, Bangladesh. Journal of Bangladesh Chemical Society $24(2), 165-172$.

3. Codex Alimentarius 1997. Food and Nutrition Division. Food Standards. Viale delle Terme di Caracalla, Rome, Italy.

4. Demirezen, D. and Uruc, K. 2006. Comparative study of trace elements in certain fish, meat and meat products. Meat science $74,255-260$,

5. Emin, S., Yordanova, K., Dimov, D., Ilieva, V., Koychev, A., Prakova G., Vlaykova, T. 2010. Total antioxidant capacity of plasma determined as ferrous reducing ability of plasma in patients with copd. Trakia Journal of Sciences 8, 205-213

6. European Commission (EC) 1999. Unit B3-management of scientific committees II: Opinion of the scientific committee on veterinary measures relating to public health. Assessment of 
potential risks to human health from hormone residues in bovine meat and meat products. 30 April.

7. European commission (EC) 2004. EU Pesticides database, http://ec.europa. eu /food/plant/ pesticides/ eu pesticides database/public/? Event=active substance. selection language $=$ EN

8. European Union (EU) 2006. COMMISSION REGULATIO (EC) No 1881/2006 of 19 December 2006 setting maximum levels for certain contaminants in foodstuffs (Text with EEA relevance) Official Journal of European Union 20.12.2006 L 364/5

9. FAO/WHO. 2016. Manual on development and use of FAO and WHO specifications for pesticides. First edition - third revision. http://apps who int/iris/bit stream/10665/246192/1/WHOHTMNTD-WHOPES-2016.4-eng pdf

10. FAO/WHO. 2017. Pesticides residues in foods. FAO plant production and protection 232. Joint FAO/WHO Meeting on Pesticide Residues. Food

11. Heitzman, R.J. 1990. "Veterinary Drug Residues" Residues in food producing animals and their products: Reference Materials and Methods, Second Edition, Published on behalf of Commission of the European Communities.

12. Herrera, A., Arino, A.A., Conchello, M.P., Lazaro, R., Bayarri, S., Perez, C. 1994. Organochlorine Pesticide Residues in Spanish Meat Products and Meat of different species. Journal of Food Protection 57 (5), 441-444

13. JAOAC (Journal of Association of Official Analytical Chemists), 57, 604 (1974). Detection of pesticides using Gas Chromatography (GC.)

14. Kaiser, J. 2000. Endocrine disrupters: Panel cautiously confirms low-dose effects. Science 290, 695-697.
15. Rama Prasad, J., SuhasSouri, J., Kumar, A., Sharma' S.G., Erage C.M. 2016.Contaminants and Toxins in Foods and Feeds. International Journal of Enviromental Science and Technology 2 (1), $82-89$.

16. R- Biopharm AG-Darmstadt, Germany: RIDASCREEN® Trenbolon, Enzyme Immunoassay for the quantitive analysis of trenbolon (ART, No.: R2601).

17. R- Biopharm AG-Darmstadt, Germany: RIDASCREEN® Zeranol, Enzyme Immunoassay for the quantitive analysis of zeranol (ART, No.: R33o1)

18. S.A.S. Institute, Inc. (2001): Users' Guide Statititics, S.A.S. Institute, Inc. Cary, North Carolina, America.

19. Toffolatti, L. Rosa, G.L., Patarnello, T., Romualdi C.I., Merlanti, R., Montesissa, C., Poppi, L., Castagnaro, M., Bargelloni, L. 2006. Expression analysis of androgen responsive genes in the prostate of veal calves treated with anabolic hormones. Domestic Animal Endocrinology 30, 38 - 55.

20. WHO (2000). Lead In: Safety Evaluation of certain food additives and contaminations, fifty-fifth meeting of the joint FAO/WHO Expert Committee on Food Additives (JECFA), Geneva; WHO Food Additives Series, 44, World Health Organization, Geneva, $273-312$.

21. World Health Organization (WHO), 2001. Cadmium.In; safety evaluation of Certain Food Additives and Contaminants. Fifty Fifth meeting of the joint FAO/WHO Expert Committee On Food Additives (JECFA). Geneva: WHO Food Additives Series 46, $247-305$.

22. World Health Organization (WHO) 2009. International Agency for Research on cancer, LARC Monographs on the evaluation of Carcinogenicity: an updating of LARC Monographs $1-42$. Suppl. 7 WHO: LARC, Lyon, France Pp 440. 